\title{
Implications of Trade Policies in Segmented Factor Markets-A General Equilibrium Approach
}

\author{
Soumyatanu Mukherjee ${ }^{1 *}$, Shreya Banerjee ${ }^{2}$ \\ ${ }^{1}$ Faculty Block I, IIMK Campus, Indian Institute of Management Kozhikode, Kozhikode, India \\ ${ }^{2}$ IIMK Campus, Kozhikode, India \\ Email: ^smukherjee@iimk.ac.in, shreyab660@gmail.com
}

How to cite this paper: Mukherjee, S. and Banerjee, S. (2018) Implications of Trade Policies in Segmented Factor Markets-A General Equilibrium Approach. Theoretical Economics Letters, 8, 780-792. https://doi.org/10.4236/tel.2018.85054

Received: January 17, 2018

Accepted: March 24, 2018

Published: March 27, 2018

Copyright ( 92018 by authors and Scientific Research Publishing Inc. This work is licensed under the Creative Commons Attribution International License (CC BY 4.0).

http://creativecommons.org/licenses/by/4.0/

\section{cc) (7) Open Access}

\begin{abstract}
This paper, using a three-sector full-employment general equilibrium model with segmented domestic factor markets, explains how and under what conditions a policy of import restriction using tariffs can be beneficial for a small, open economy compared to the import liberalisation policy, contrary to the conventional results. Also, inflows of foreign-owned capital to an export sector within the economy's export processing zone coupled with labour-augmenting type technology transfer, with protected import-competing sector, can improve national income, even without any distortion in the formal sector labour market. This simple application of competitive trade models establishes the fact that trade restrictions can promote growth and attract FDI for the developing countries, even when foreign capital enters one specific export sector of the economy.
\end{abstract}

\section{Keywords}

Tariff, Foreign Capital, Segmented Factor Markets, General Equilibrium

\section{Introduction}

Although the World Trade Organization (WTO) promotes and supports multilateral trade liberalization, many developing countries continue to maintain relatively high tariffs despite committing to tariff reductions. Also there are examples where some countries initially implemented tariff reform enthusiastically, had to increase the tariff rates at least for the time being ${ }^{1}$. Empirical evidence, ${ }^{1}$ One such example is Pakistan. On October 1995, Pakistan imposed additional import duties to improve trade balance, which had deteriorated drastically following implementation of trade liberalisation policies in the initial phase of reforms. 
such as Yanikkaya [1], finds that trade barriers can be beneficial for developing economies, and the evidence that liberalizing trade is beneficial and is not compelling. The costs of high tariffs include reallocation of resources towards import-competing goods in which the country has no comparative advantage, and away from potentially efficient export sectors. There may also be benefits, such as advocated by the infant industry argument, strategic trade policies and tariff-jumping theory that high tariffs encourage FDI by multinationals, which want to sell in the domestic market [2] [3]. Counties keen to attract FDI may be less inclined to attract to implement tariff reform seriously. Many developing countries also exhibit capital market distortion in the unorganized (informal) sector due to the fragmented interest rate structure, with constrained credit to the informal sector at a higher interest rate than facing the formal sector. The informal producers do not have access to credit from formal institutions and therefore, have to depend on the informal credit market, where rate of interest is higher. To the best of our knowledge, no theoretical contribution has introduced capital market distortion in the domestic economy and deviated from the assumption of perfect substitutability between domestic and foreign capital, in the course of identifying how and under what conditions a policy of import restriction using tariffs can be beneficial for a small, open economy, as opposed to the import liberalization policy.

This paper incorporates distortions in both factor markets in a $3 \times 3$ general equilibrium model of production and trade to explore the welfare implications of a protectionist policy characterized by increase in tariff rate on the protected domestic import-competing sector and a tariff reform in the import-competing sector, when foreign capital is specific only to the export sector within the export processing zones (EPZ hereafter) of the economy. For convenience, I consider per capita national income as a crude indicator of the economy's social welfare. This may be inappropriate in the presence of high income inequality. ${ }^{2}$ However, the focus of this paper is not on income inequality.

Theoretical studies have investigated the effect of FDI directed in the foreign enclave (like an export processing zone) in developing economies-using a hybrid of both Ricardo-Viner and Heckscher-Ohlin structures [5] [6] [7] [8] [9]. Beladi and Marjit [7] find that the inflow of FDI to the EPZ will be immiserising in a small, open economy using a $3 \times 3$ full-employment model with tradable final commodities and a protected import-competing sector, which is the relatively capital-intensive sector of the economy.

Using a three-sector full employment model (but without tariff protection in the import-competing sector), Din [8] showed an inflow of foreign capital with full repatriation of foreign capital income to the EPZ may raise the national income in the presence of non-traded intermediate input and the subsequent backward linkages induced by the use of that non-traded intermediate input in

${ }^{2}$ In such cases the welfare measure of Sen [4], defined as the per-capita income multiplied by one minus the Gini-coefficient of the income distribution, is an appropriate measure of welfare of the different groups of population. 
the EPZ. Yabuuchi [9] extended the Din [8] framework under variable returns to scale (VRS) to show in case of a traded intermediate input that, national income may increase if there are output-generated increasing returns in the EPZ and in at least one of the two domestic sectors.

Yet none of these papers considered the possibilities of having dualism simultaneously in both capital and labour markets, or in other words, segmentations within domestic factor markets. At the same time, if foreign capital inflow takes place, the host country gets benefit from the superior technical know-how and skills of the investing country. These new ideas lead to transfer of technology from the foreign producers to the citizens of the recipient country as a spill-over effect on it, known as "contagion hypothesis" [10] [11] [12]. Empirical evidence [13] [14] suggests that technology transfer in developing countries takes place mainly through the FDI channel. The main motive behind the FDI by the multinational enterprises (MNEs) in the developing countries is that they get higher rate of return on their capital in these countries relative to the international market. Therefore, the supply of foreign capital in our small open economy is a positive function of the net return to foreign capital in this recipient country.

This paper assumes a $3 \times 3$ production structure where FDI enters, by the means of reduction in tax rate on foreign capital income, a specific export sector of the economy within the EPZ which uses foreign capital as a specific input; and the efficiency enhancement of labor is associated with the labor force employed in that sector. On the top of that, I have considered segmented domestic capital market. This analysis reveals that contrary to the existing theoretical results, if FDI to the EPZ is accompanied by labor-augmenting technology transfer in this small open developing economy with segmented domestic factor markets, welfare can improve although foreign capital does not enter the tariff protected import-competing sector.

It is important to mention that our model is different from the standard Harris-Todaro (1970) type structure, featuring rural-urban migration with the existence of urban unemployment. I consider a three sector full-employment general equilibrium framework with unionised and flexible wage segments. This set-up should be viewed as a $3 \times 3$ extension of Beladi et al. [15]. ${ }^{3}$ The workers, who do not find jobs in the unionised sector, get absorbed in the competitive flexible wage segments. This description fits well with the typical developing country like India, where rate of unemployment among the unorganized workers is very low, since they cannot survive without jobs.

The next section describes the structure of our general equilibrium model and implications of these policies on the national income of a small, open economy while the last section briefly describes the concluding remarks and the policy implications of the derived results.

\footnotetext{
${ }^{3}$ This paper may be viewed as a special case of the class of competitive trade models in Mukherjee [16] [17]; since our economy comprises only three tradable goods producing sectors. I have not considered the existence of non-traded commodities since our only focus is on the role of factor market distortions and technology transfer.
} 


\section{The Model}

Consider a small open developing economy consisting of a domestic zone and an EPZ. Within the domestic zone, there are two sectors: sectors 1 and 3. Sector 2 is exclusively within the EPZ using foreign capital as a specific input. Sectors 1 and 3 use labour and domestic capital to produce $X_{1}$ and $X_{3}$ respectively. $X_{2}$ is produced by sector 2 using labor and foreign capital. Sector 3 is the import-competing sector, protected by an import tariff. ${ }^{4}$ Labor in sector 1 earns a competitive wage but there is a unionised wage in sector 3 .

\subsection{Modelling Assumptions}

1) Wages in sector 3 is institutionally given at a higher rate $W^{*}>W^{5}$.

2) Both sector 1 and sector 2 are in close vicinity and labor is perfectly mobile between these two sectors. Workers who do not get a job in sector 3 will be absorbed either in sector 1 or sector 2 at a competitive wage. So there is no unemployment of labor in this model.

3) Sector 1 (the unorganized or informal domestic sector) faces imperfection in credit market, with the rental of domestic capital being higher than that in the organized (formal) import-competing sector (sector 3).

4) All goods are traded internationally and their prices are internationally given owing to the small open economy assumption. The product markets are perfectly competitive and production functions follow CRS technology.

5) Without any loss of generality, we reasonably assume that the protected import-competing manufacturing sector (sector 3 ) is more capital-intensive relative to the informal agricultural sector (sector 1 ) in physical and value sense; i.e.

$$
\begin{aligned}
\frac{a_{K 3}}{a_{L 3}}> & \frac{a_{K 1}}{a_{L 1}} \Leftrightarrow \lambda_{L 1} \lambda_{K 3}>\lambda_{L 3} \lambda_{K 1} \\
& \Leftrightarrow \theta_{L 1} \theta_{K 3}>\theta_{K 1} \theta_{L 3} .
\end{aligned}
$$

6) Production functions in all sectors are of Cobb-Douglas type. ${ }^{6}$

The following notations are used:

$W=$ Competitive informal wage rate for labor;

$W^{*}=$ Institutionally given wage rate in domestic formal manufacturing sector;

$r_{D}=$ Cost (rental rate) of domestic capital $\left(\bar{K}_{D}\right)$ in sector 3;

$R_{D}=$ Cost (rental rate) of domestic capital in informal credit market of sector 1 ;

$$
\begin{aligned}
& r_{F}=\text { Rental rate of foreign capital }\left(K_{F}\right) ; \\
& X_{i}=\text { Output of sector } i,(i=1,2,3)
\end{aligned}
$$

\footnotetext{
${ }^{4}$ We assume ad-valorem equivalence of any quantitative or other restrictions on imports, such as quotas.

${ }^{5}$ We do not model this wage-fixation explicitly. Chaudhuri [18] provides an explanation of how this happens by prior negotiations with the trade unions as an outcome of collective bargaining process. Also see Mukherjee [19].

${ }^{6}$ This is a simplifying assumption. It implies that elasticity of substitution between factors of production in each sector is unity.
} 
$P_{i}=$ International price of good $i$

$a_{j i}=$ Amount of the $j^{\text {th }}$ factor used to produce 1 unit of the $i^{\text {th }}$ good;

$t=$ Ad-valorem rate of tariff;

$\theta_{j i}=$ Cost share of factor $j$ in the production of good $i$

$\lambda_{j i}=$ Share of sector $i$ in the total employment of factor $j$;

$\wedge=$ Proportional change.

Under perfect competition we have the usual zero-profit conditions (price-unit cost equality)

$$
\begin{gathered}
W a_{L 1}+R_{D} a_{K 1}=P_{1} \\
W a_{L 2}+r_{F} a_{K 2}=P_{2} \\
W^{*} a_{L 3}+r_{D} a_{K 3}=P_{3}(1+t)
\end{gathered}
$$

There exists following functional relationship between $R_{D}$ and $r_{D}$;

$$
R_{D}=\rho r_{D} \text { with } \rho>1 .
$$

Here $\rho$ represents the degree of distortion in the unorganized/informal credit market. The informal moneylenders are able to borrow funds from the domestic formal sector at the market rate $r_{D}$, re-lends to the domestic informal borrowers and by this way maximizes net interest income. Therefore, it is realistic to model the rental rate in the informal sector (sector 1) is positively related to and strictly higher than the cost of capital in sector 3 . The lower the number of alternative sources of credit to the borrowers in the informal sector, the higher is the degree of imperfection of the informal credit market and thereby the power of the informal sector lenders to markup informal rental rates over those in sector 3; i.e., greater value of $\rho$.

Therefore, one can write Equations (1) as:

$$
W a_{L 1}+\rho r_{D} a_{K 1}=P_{1}
$$

The amount of credit allocated to the informal sector is a positive function of the return differential between the two capital markets. Therefore, as long as $\rho>1$, informal capital market exists and thus the segmentation in domestic capital market exists. $^{7}$

$$
K_{1}\left(R_{D}-r_{D}\right)=K_{1}\left\{r_{D}(\rho-1)\right\} \text {. So when }\left(R_{D}-r_{D}\right) \geq 0, K_{1}^{\prime}(.) \geq 0 .
$$

So full utilization of informal credit implies:

$$
a_{K 1} X_{1}=K_{1}\left\{r_{D}(\rho-1)\right\}
$$

Note that Equation (6) is not an independent equation.

Sector 3 uses the formal credit. The equilibrium in the formal credit market

${ }^{7}$ It is worth to mention that Chaudhuri [18] has considered the dualism in capital/credit market in the same fashion to consider the welfare implications of different liberalisation policies. However, that paper considered a Harris-Todaro type economy and assumed perfect substitutability between domestic and foreign capital. This paper, on the other hand, has considered a full-employment model with segmentation in labour market as well; also in our model foreign capital is specific to a particular export sector of the economy within the EPZ. The justification for considering full-employment structure with segmented labour market has been discussed in the introduction. 
ensures that

$$
a_{K 3} X_{3}=\bar{K}_{D}-K_{1}\left\{r_{D}(\rho-1)\right\}
$$

Similarly, for foreign capital

$$
a_{K 2} X_{2}=K_{F}
$$

Full-employment condition for labor implies (normalizing total labor endowment to unity)

$$
a_{L 1} X_{1}+a_{L 2} X_{2}+a_{L 3} X_{3}=1
$$

Domestic welfare of the economy is measured by national income at world prices, given by

$$
Y=W+\left(W^{*}-W\right) a_{L 3} X_{3}+r_{D} \bar{K}_{D}+\left(R_{D}-r_{D}\right) K_{1}-t P_{3} X_{3}
$$

Let us consider that the income from foreign capital is completely repatriated back to the source country.

We have seven endogenous variables $W, r_{D}, r_{F}, K_{1}, X_{1}, X_{2}, X_{3}$ in this system to be solved from seven independent Equations (1.1), (2), (3), (5), (7), (8) and (9). $r_{D}$ is determined from Equation (3) given the unionised wage and exogenous price of the importable. Substituting $r_{D}$ in Equation (1.1), given $\rho$, one can obtain $W$. Finally from Equation (2) $r_{F}$ is found given $W$. Once factor prices are known, factor-coefficients $a_{j i}$ s are also known. Now using the value of $r_{D}$ and given $\rho$, we can find $K_{1}($.$) from Equation (5). Then simultaneously$ solving Equations (7), (8) and (9) we get $X_{1}, X_{2}$ and $X_{3}$.

Welfare implication of protectionist policy versus import liberalization policy.

Totally differentiating Equations (1.1), (2)-(3), applying envelope conditions and using Cramer's rule one obtains

$$
\begin{gathered}
\hat{W}=-\left(T \hat{t} \theta_{K 1} / \theta_{L 1} \theta_{K 3}\right) \\
\hat{r}_{D}=\left(T \hat{t} / \theta_{K 3}\right) \\
\hat{r}_{F}=\left(T \hat{t} \theta_{K 1} \theta_{L 2} / \theta_{L 1} \theta_{F 2} \theta_{K 3}\right)
\end{gathered}
$$

where $T=(t / 1+t)>0$. Total differentiation of (7) and using Equations (11)-(13), we obtain (owing to "Modelling assumption" (6)

$$
\hat{X}_{3}=\left\{T \hat{t}\left(\theta_{L 3}-r_{D}(\rho-1) K_{1}^{\prime}(.) / a_{K 3} X_{3}\right)\right\} / \theta_{K 3}
$$

Differentiating Equation (10) with respect to $t$, we get the following:

$$
\begin{aligned}
\mathrm{d} Y / \mathrm{d} t= & \left(1 / \theta_{K 3}\right)\left[\left(T \lambda_{L 3} / t\right)\left\{\left(W^{*}-W\right)\left(1-r_{D}(\rho-1) K_{1}^{\prime}(.) / a_{K 3} X_{3}\right)+r_{D}\left(a_{K 1} / a_{L 1}\right)\right\}\right. \\
& +\left(T_{D} / t\right)\left\{\left(\bar{K}_{D}+(\rho-1) K_{1}(.)+(\rho-1)^{2} r_{D} K_{1}^{\prime}(.)\right)-\left(a_{K 1} / a_{L 1}\right)\right\} \\
& \left.-P_{3} X_{3}\left\{1+T\left(\theta_{L 3}-r_{D}(\rho-1) K_{1}^{\prime}(.) / a_{K 3} X_{3}\right)\right\}\right]
\end{aligned}
$$

A little bit of simplification yields, 


$$
\begin{aligned}
& \mathrm{d} Y / \mathrm{d} t \\
& =\left(1 /(1+t) \theta_{K 3}\right)\left[X_{3}\left\{\left(W^{*}-W\right) a_{L 3} \theta_{K 3}-t P_{3}\right\}\left\{1+\left(\theta_{L 3}-r_{D}(\rho-1) K_{1}^{\prime}(.) / a_{K 3} X_{3}\right)\right\}\right. \\
& \left.+r_{D}\left\{\left(\bar{K}_{D}+(\rho-1) K_{1}(.)+(\rho-1)^{2} r_{D} K_{1}^{\prime}(.)\right)-\left(a_{K 1} / a_{L 1}\right)+\lambda_{L 3}\left(a_{K 1} / a_{L 1}\right)\right\}\right]
\end{aligned}
$$

We have $\mathrm{d} t>0$ when a protectionist policy is adopted in the import-competing sector 3 and $\mathrm{d} t<0$ under the policy of trade-liberalization in sector 3 (where " $t$ " is the ad-valorem rate of tariff).

Case (I): $\mathrm{d} t>0$. Then we have from Equations (11)-(13):

$\hat{W}<0, \hat{r}_{D}>0$ and $\hat{r}_{F}>0$. So from Equation (14), we have $\hat{X}_{3}>0$ under the sufficient condition $1>\theta_{L 3}>\left\{r_{D}(\rho-1) K_{1}^{\prime}(.) / a_{K 3} X_{3}\right\}$. In Equation (16) we find that the sign of the term $\left\{\left(\bar{K}_{D}+(\rho-1) K_{1}()+.(\rho-1)^{2} r_{D} K_{1}^{\prime}().\right)-\left(a_{K 1} / a_{L 1}\right)\right\}$ is positive. This is because given our assumption that sector 3 is more capital-intensive than sector $1,\left(a_{K 1} / a_{L 1}\right)$ should be less than the ratio of aggregate stock of domestic capital to labour in the economy ${ }^{8}$. Therefore from Equation (16) it follows that $(\mathrm{d} Y / \mathrm{d} t)>0$ if $\left(W^{*}-W\right) a_{L 3} \theta_{K 3}>t P_{3}$.

Therefore we can state the following proposition:

PROPOSITION 1. In a small open economy with segmented factor markets, a protectionist policy in the form of increase in the ad-valorem rate of tariff on the importable can increase welfare if

1) $\theta_{L 3}>\left\{r_{D}(\rho-1) K_{1}^{\prime}(.) / a_{K 3} X_{3}\right\}$ and;

2) $\left(W^{*}-W\right) a_{L 3} \theta_{K 3}>t P_{3}$.

-hold simultaneously. However in the absence of factor market distortions in the domestic factor markets, welfare will definitely deteriorate as a consequence of a protectionist policy in the import-competing sector.

Intutive proof. As $t$ increases, the domestic price of the importable rises. So given the pegged wage $W^{*}$ interest rate in sector $3, r_{D}$, rises. To satisfy the zero-profitability condition for sector 1 , competitive wage, $W$, will fall. As $r_{D}$ rises, the formal-informal interest differential, $\left(R_{D}-r_{D}\right)$ rises too. So credit allocated to sector $3,\left\{\bar{K}_{D}-K_{1}().\right\}$, will fall. Therefore two opposite effects on $X_{3}$ are now operating. Due to rise in $r_{D}$ capital-output ratio in sector 3, $a_{K 3}$, will fall and hence $X_{3}$ will rise for a given supply of credit, $\left\{\bar{K}_{D}-K_{1}().\right\}$. On the other hand, given $a_{K 3}$ lowering the availability of credit to sector 3 will put a downward pressure on $X_{3}$.

Yet if the sufficient condition $\theta_{L 3}>\left\{r_{D}(\rho-1) K_{1}^{\prime}(.) / a_{K 3} X_{3}\right\}$ is satisfied, sector 3 will expand. So the aggregate wage-income of the workers are affected due to:

- Fall in $W$, and

- Expansion of the higher wage-paying sector 3 and the consequent flow of the workers to sector 3 .

${ }^{8}$ Note that aggregate labor endowment of the economy has been normalized to unity. 
Also as $r_{D}$ rises, the presence of credit market imperfection in sector 1 would make the rise in aggregate rental income from domestic capital more likely. From Equation (15), aggregate domestic factor income will rise as $\left\{\left(\bar{K}_{D}+(\rho-1) K_{1}()+.(\rho-1)^{2} r_{D} K_{1}^{\prime}().\right)-\left(a_{K 1} / a_{L 1}\right)\right\}>0$. But the cost of tariff protection will also rise since $X_{3}$ rises under the sufficient condition $\theta_{L 3}>\left\{r_{D}(\rho-1) K_{1}^{\prime}(.) / a_{K 3} X_{3}\right\}$. This will negatively affect welfare. However from Equation (17) it follows that welfare can still improve if $\left(W^{*}-W\right) a_{L 3} \theta_{K 3}>t P_{3}$. But in the absence of factor market distortions it is easy to show that welfare will deteriorate if $\left(a_{K 1} / a_{L 1}\right)<1$. This sufficiency condition is more plausible to hold in our framework since sector 1 is the relatively less capital-intensive sector in the domestic zone. (Q.E.D.)

Case (II): In the presence of distortions in domestic factor markets and sector-specific foreign capital, removal of protectionism may not be the first-best policy to adopt.

Intuitive proof. When $\mathrm{d} t<0$, we have from Equations (11)-(13):

$$
\hat{W}>0, \hat{r}_{D}<0 \text { and } \hat{r}_{F}<0 .
$$

The fall in $r_{D}$ will induce the sector 3 producers to use more capital per-unit of production, which means $a_{K 3}$ will now rise and so given the supply of capital to sector $3, X_{3}$ will fall. But since $\left(R_{D}-r_{D}\right)$ falls, $\left\{\bar{K}_{D}-K_{1}().\right\}$ rises as well. This will encourage sector 3 producers to use more capital. However if $1>\theta_{L 3}>\left\{r_{D}(\rho-1) K_{1}^{\prime}(.) / a_{K 3} X_{3}\right\}$ holds, $\hat{X}_{3}<0$. From Equation (15), we find that aggregate factor income will fall since the sign of the term $\left\{\left(\bar{K}_{D}+(\rho-1) K_{1}()+.(\rho-1)^{2} r_{D} K_{1}^{\prime}().\right)-\left(a_{K 1} / a_{L 1}\right)\right\}$ would still be positive as the capital-labor ratio used in per-unit of production in the relatively less domestic capital-intensive sector of the economy (i.e., sector 1 ) should always be less than the ratio of aggregate stock of domestic capital to labor in the economy. But distortionary costs of tariff protection in sector 3 will also fall. Hence welfare will fall if the positive effect of reduction in costs of tariff protection, measured by the term $P_{3} X_{3}\left\{1+T\left(\theta_{L 3}-r_{D}(\rho-1) K_{1}^{\prime}(.) / a_{K 3} X_{3}\right)\right\}$, is not significantly higher to outweigh the fall in aggregate factor income due to reduction in tariff. This is followed from the same sufficiency condition obtained in Equation (16) $\left[\left(W^{*}-W\right) a_{L 3} \theta_{K 3}>t P_{3}\right]$. (Q.E.D.)

It should be pointed out that even when one measures welfare using a quasi-concave social welfare function, which captures demand side and supply side distortions, the qualitative results here would be unaffected.

\subsection{FDI to the EPZ with Technology Transfer}

In this set-up we shall use some of the following additional symbols:

$h=$ efficiency of each laborer;

$b=$ ad-valorem rate of tax on income from foreign capital.

And

$$
\text { Supply of foreign capital, } K_{F}=K_{F}\left\{r_{F}(1-b)\right\}, K_{F}^{\prime}(.)>0
$$


FDI inflow to sector 2 (foreign enclave) is now associated with efficiency gain of each worker employed in sector 2, given as:

$$
h=h\left[K_{F}\left\{r_{F}(1-b)\right\}\right], h^{\prime}>0
$$

So the zero-profit condition for sector 2 now becomes:

$$
W h(.) a_{L 2}+r_{F} a_{K 2}=P_{2}
$$

So full-employment condition for labor now becomes:

$$
a_{L 1} X_{1}+h(.) a_{L 2} X_{2}+a_{L 3} X_{3}=h\left[K_{F}\left\{r_{F}(1-b)\right\}\right]
$$

where after normalizing physical units of labor endowment to unity, $h($. would become the efficiency units of labor endowment of the economy.

In this decomposable structure a foreign capital inflow to the EPZ, brought about by a reduction in tax rate, will not alter the input prices. Therefore $r_{D}$ and $R_{D}$ will not change and consequently, no change in domestic capital allocation between sectors 1 and 3 . Hence, we can express the full utilization condition of domestic capital as:

$$
a_{K 1} X_{1}+a_{K 3} X_{3}=K_{D}
$$

Full-utilization condition for foreign capital now implies:

$$
a_{K 2} X_{2}=K_{F}\left\{r_{F}(1-b)\right\}
$$

National income at world prices will now be expressed as:

$$
Y=W h(.)+\left(W^{*}-W\right) a_{L 3} X_{3}+r_{D} \bar{K}_{D}+\left(R_{D}-r_{D}\right) K_{1}+b r_{F} K_{F}(.)-t P_{3} X_{3}
$$

where $b_{F} K_{F}($.$) is the tax revenue collected from the foreign capital income.$

Note that now we have fully decomposable price system, where the factor prices, including rental to foreign capital $\left(r_{F}\right)$, are determined in terms of internationally given commodity prices alone. So a foreign capital inflow to the export sector of the economy (i.e., the EPZ), brought about by a reduction in the tax rate on foreign capital income, will not alter the factor prices faced by the competitive producers.

Total differentiation of Equations (20)-(23) and simple manipulations will give us the following results (see Appendix):

$$
\begin{aligned}
\hat{X}_{3}= & -\frac{\lambda_{K 1} b r_{F} K_{F}^{\prime}}{|\lambda|} \hat{b}\left[\frac{h^{\prime}\left(1-\lambda_{L 2}\right)}{h}-\frac{\lambda_{L 2}}{K_{F}}\right] \\
\hat{X}_{1}= & -\frac{\lambda_{K 3} b r_{F} K_{F}^{\prime}}{|\lambda|} \hat{b}\left[\frac{\lambda_{L 2}}{K_{F}}-\frac{h^{\prime}\left(1-\lambda_{L 2}\right)}{h}\right] \\
\mathrm{d} Y / \mathrm{d} b= & -r_{F}\left[W h^{\prime} K_{F}^{\prime}+\left(b r_{F} K_{F}^{\prime}-K_{F}(.)\right)\right]-\lambda_{K 1}\left(r_{F} K_{F}^{\prime} X_{3} /|\lambda|\right) \\
& \times\left\{\left(W^{*}-W\right) a_{L 3}-t P_{3}\right\}\left[\left\{\left(1-\lambda_{L 2}\right) h^{\prime} / h\right\}-\left(\lambda_{L 2} / K_{F}\right)\right]
\end{aligned}
$$

where $|\lambda|=\left(\lambda_{L 3} \lambda_{K 1}-\lambda_{L 1} \lambda_{K 3}\right)<0$ since we retain the "Modelling assumption" No. 5 that sector 3 is relatively capital-intensive vis-à-vis sector 1 in value and physical sense. 
Therefore, $\left(\hat{X}_{3} / \hat{b}\right) \lesseqgtr 0$ and $\left(\hat{X}_{1} / \hat{b}\right) \gtreqless 0$ if $\left(h^{\prime} K_{F} / h\right) \lesseqgtr\left\{\lambda_{L 2} /\left(1-\lambda_{L 2}\right)\right\}$ and $(\mathrm{d} Y / \mathrm{d} b) \leq 0$ if

1) $\left[\lambda_{K 1}\left\{\left(W^{*}-W\right) a_{L 3}-t P_{3}\right\}\right]\left[\left\{\left(1-\lambda_{L 2}\right) h^{\prime} / h\right\}-\left(\lambda_{L 2} / K_{F}\right)\right] \leq 0$ and/or

4) $\left(b r_{F} K_{F}^{\prime}-K_{F}().\right) \geq 0$.

This leads to the following proposition:

PROPOSITION 2. An FDI inflow to the EPZ brought about by a fall in the tax rate on income from FDI may be beneficial for the recipient country if either or both of

1) $\lambda_{K 1}\left\{\left(W^{*}-W\right) a_{L 3}-t P_{3}\right\}\left[\left\{\left(1-\lambda_{L 2}\right) h^{\prime} / h\right\}-\left(\lambda_{L 2} / K_{F}\right)\right] \leq 0$;

2) $\left(b r_{F} K_{F}^{\prime}-K_{F}().\right) \geq 0$.

-hold.

Intuitive proof. An FDI inflow to sector 2 (EPZ), brought about by a reduction in the tax rate on foreign capital income, will raise the labor demand by this sector and enhances efficiency of the workers tied to this sector, raising the effective labor endowment of the economy. Therefore, depending on the net availability of labor in the domestic zone, there will be a "Rybczynski effect" in the Heckscher-Ohlin "nugget" formed by the two domestic sectors-sector 1 and sector 3. However the relatively capital-intensive protected import-competing formal sector will expand (or remains the same or contract) according to the direction of this Rybczynski effect; i.e., if $\left(h^{\prime} K_{F} / h\right) \lesseqgtr\left\{\lambda_{L 2} /\left(1-\lambda_{L 2}\right)\right\} .{ }^{9}$ Therefore the distortionary cost of tariff-protection in the import-competing formal sector increases (or remains unchanged or falls). We call this the "output effect" (of the formal sector).

Due to the presence of labor market imperfection in the formal sector we have positive wage-differential between the two domestic sectors. Given the effective labor endowment, the aggregate wage-income in the economy will be unidirectional to any change in the higher wage-paying formal sector.

The rise in the effective labor endowment of the economy implies further favorable impact on welfare, captured by the term $\left[-W h^{\prime} K_{F}^{\prime} r_{F} d b\right]>0$.

Finally the FDI inflow induced by a fall in tax on income from FDI would have a favorable impact (no impact) on economy-wide national income through the increase (no change) in tax revenue if $\left(b r_{F} K_{F}^{\prime}-K_{F}().\right)>0$ or $=0$.

Even when we ignore this tax revenue effect (i.e., consider the case when $b r_{F} K_{F}^{\prime}=K_{F}$ ), in the absence of any labor market imperfection in the formal sector welfare may still improve. The efficiency gain in labor force engaged in sector 2 (due to the labor-augmenting nature of technology transfer) will make the direction of the Rybczynski effect in the domestic zone (i.e., within the

\footnotetext{
${ }^{9}$ Note also that the direction of change in output-composition in the domestic zone will depend only on one Rybczynski effect in the domestic zone; which would be either in favor of the formal sector (when net availability of labor in the domestic zone decreases) or against the formal sector (when net availability of labor in the domestic zone increases) or there would not be any Rybczynski effect (when net availability for labor in the domestic zone does not change).
} 
"nugget") ambiguous. So even when the wage-gap between the two domestic sectors does not exist the distortionary cost of tariff-protection may fall (remain unchanged). On the top of that, this efficiency gain in the laborers working in sector 2 will be transmitted to an increase in effective labour endowment of the economy, which unambiguously improves welfare. (Q.E.D.)

It is also evident from the above set-up that if $\hat{t} \lessgtr 0$, then $\hat{r}_{F} \lessgtr 0$ and $\hat{r}_{D} \lessgtr 0$.

Hence, a protectionist policy in the form of tariff in the import-competing sector will lead to increase in returns to both domestic and foreign capital, which would encourage fresh inflows of foreign capital to the EPZ. But an import-liberalization policy characterized by a tariff reform in sector 3, will have exactly opposite implications and therefore will act as a deterrent to foreign capital for this small, open economy.

\section{Concluding Remarks}

This analysis shows in a $3 \times 3$ full-employment structure with segmentations in factor markets that a protectionist policy in the form of increase in tariffs on imports will be superior to the policy of import-liberalization, in terms of the impact on per capita income. If foreign capital enters the export sector of the economy within the EPZ with labor-augmenting type technology transfer, welfare in this small, open economy can improve even in the presence of segmented domestic factor markets. This result is in sharp contrast to the existing theoretical literature and suggests that government may adopt investment liberalization policy and a policy of labor market reform simultaneously in the presence of technology transfer. Also, it is interesting to note that a protectionist policy in the domestic import-competing sector (increase in tariff rate on importable) in this set-up will lead to an increase in the return to foreign capital, which will encourage FDI to the export sector of the economy within the EPZ. Most importantly, unlike most of those existing theoretical papers investigated welfare implications of trade and investment liberalization, the results obtained in this paper do not depend on the perfect substitutability assumption between domestic and foreign capital. Therefore, this paper has served to provide another explanation, in a more convincing way than the standard "tariff-jumping theory", why the developing countries are reluctant to adopt trade reform policies, but luring for foreign capital during the last couple of decades compared to the developed nations. As a future research agenda, one should bring in search frictions to the sector 3 labor market within this framework.

\section{References}

[1] Yanikkaya, H. (2003) Trade Openness and Economic Growth: A Cross-Country Empirical Investigation. Journal of Development Economics, 72, 57-89. https://doi.org/10.1016/S0304-3878(03)00068-3

[2] Motta, M. (1992) Multinational Firm and Tariff-Jumping Argument: A Game Theoretic Analysis with Some Unconventional Conclusions. European Economic Review, 36, 1557-1571. https://doi.org/10.1016/0014-2921(92)90006-I 
[3] Yanagawa, N. (1990) Foreign Direct Investment for Tariff-Jumping. Economic Studies Quarterly, 41, 353-366.

[4] Sen, A.K. (1974) Informal Bases of Alternative Welfare Approaches: Aggregation and Income Distribution. Journal of Public Economics, 4, 387-403.

https://doi.org/10.1016/0047-2727(74)90006-1

[5] Hamada, K. (1974) An Economic Analysis of the Duty Free Zone. Journal of International Economics, 4, 225-241. https://doi.org/10.1016/0022-1996(74)90044-0

[6] Hamilton, C. and Svensson, L.O. (1982) On the Welfare Effects of a "Duty Free" Zone. Journal of International Economics, 13, 45-64. https://doi.org/10.1016/0022-1996(82)90005-8

[7] Beladi, H. and Marjit, S. (1992) Foreign Capital and Protectionism. Canadian Journal of Economics, 25, 233-238. https://doi.org/10.2307/135722

[8] Din, M.-U. (1994) Export Processing Zones and Backward Linkage. Journal of Development Economics, 43, 369-385. https://doi.org/10.1016/0304-3878(94)90014-0

[9] Yabuuchi, S. (2000) Export Processing Zones, Backward Linkages, and Variable Returns to Scale. Review of Development Economics, 4, 268-278. https://doi.org/10.1111/1467-9361.00094

[10] Koizumi, T. and Kopecky, K.J. (1977) Economic Growth, Capital Movements and the International Transfer of Technical Knowledge. Journal of International Economics, 7, 45-65. https://doi.org/10.1016/0022-1996(77)90004-6

[11] Koizumi, T. and Kopecky, K.J. (1980) Foreign Direct Investment, Technology Transfer and Domestic Employment Effects. Journal of International Economics, 10, 1-20. https://doi.org/10.1016/0022-1996(80)90028-8

[12] Findlay, R. (1978) Relative Backwardness, Direct Foreign Investment and the Transfer of Technology: A Simple Dynamic Model. Quarterly Journal of Economics, 92, 1-16. https://doi.org/10.2307/1885996

[13] Mansfield, E.M. (1961) Technical Change and the Rate of Imitation. Econometrica, 9, 741-766. https://doi.org/10.2307/1911817

[14] Mansfield, E.M. (1968) Industrial Research and Technological Innovation. Norton, New York.

[15] Beladi, H., Lynda De la, V. and Marjit, S. (2012) Technological Progress with Segmented Labor Markets. Review of Development Economics, 16, 148-152. https://doi.org/10.1111/j.1467-9361.2011.00651.x

[16] Mukherjee, S. (2016) Technology, Trade and "Urban Poor" in a General Equilibrium Model with Segmented Domestic Factor Markets. International Review of Economics \& Finance, 45, 400-416. https://doi.org/10.1016/j.iref.2016.07.003

[17] Mukherjee, S. (2017) Input Trade Reform and Wage Inequality. International Review of Economics \& Finance, 51, 145-156. https://doi.org/10.1016/j.iref.2017.05.011

[18] Chaudhuri, S. (2003) How and How Far to Liberalize a Developing Economy with Informal Sector and Factor Market Distortions. The Journal of International Trade \& Economic Development, 12, 403-428. https://doi.org/10.1080/0963819032000154829

[19] Mukherjee, S. (2012) Revisiting the Apparent Paradox: Foreign Capital Inflow, Welfare Amelioration and "Jobless Growth" with Agricultural Dualism and Non-Traded Intermediate Input. Journal of Economic Integration, 27, 123-133. https://doi.org/10.11130/jei.2012.27.1.123 


\section{Appendix}

Totally differentiating Equations (20)-(22) and arranging them in matrix form we get:

$$
\left(\begin{array}{ccc}
\lambda_{L 1} & \lambda_{L 2} & \lambda_{L 3} \\
\lambda_{K 1} & 0 & \lambda_{K 3} \\
0 & \lambda_{K 2} & 0
\end{array}\right)\left(\begin{array}{c}
\hat{X}_{1} \\
\hat{X}_{2} \\
\hat{X}_{3}
\end{array}\right)=\left(\begin{array}{c}
-\left(1-\lambda_{L 2}\right)\left\{\left(h^{\prime} K_{F}^{\prime} r_{F} b \hat{b}\right) / h\right\} \\
0 \\
-\left\{\left(K_{F}^{\prime} r_{F} b \hat{b}\right) / K_{F}\right\}
\end{array}\right)
$$

Solving Equation (A10) using Cramer's rule we get $\hat{X}_{3}$ and $\hat{X}_{1}$ as in Equations (24) and (25) respectively.

Now differentiating Equation (23) with respect to $b$ we get

$$
\begin{aligned}
(\mathrm{d} Y / \mathrm{d} b)= & -W h^{\prime} K_{F}^{\prime} r_{F}+\left(W^{*}-W\right) a_{L 3}\left(\mathrm{~d} X_{3} / \mathrm{d} b\right)+(\rho-1) r_{D} a_{K 1}\left(\mathrm{~d} X_{1} / \mathrm{d} b\right) \\
& +r_{F} K_{F}(.)-b r_{F}^{2} K_{F}^{\prime}-t P_{3}\left(\mathrm{~d} X_{3} / \mathrm{d} b\right)
\end{aligned}
$$

Using Equations (24) and (25) in Equation (A2) and a little bit of simplification would yield Equation (26), from which proposition 2 is imminent.

Totally differentiating Equations (1.1), (19) and (3); applying Envelope conditions and solving by Cramer's rule it is easy to obtain:

$$
\hat{r}_{F}=\left\{\theta_{K 1} \theta_{L 2} T \hat{t} / \theta_{L 1} \theta_{K 3}\left(\theta_{F 2}+H \theta_{L 2}\right)\right\}
$$

where $H=\left\{h^{\prime} K_{F}^{\prime} r_{F}(1-b) / h\right\}>0$. Therefore as $\hat{t} \lessgtr 0, \hat{r}_{F} \lessgtr 0$. 